\title{
Marketing Mode Innovation on Small and Medium-sized Enterprises in Network Environment
}

\author{
Xiandong Zhou \\ Xiamen Institute of Software Technology, Xiamen, 361024, China
}

Keywords: network environment; small and medium-sized enterprises; network marketing; innovation countermeasures

\begin{abstract}
The small and medium-sized enterprises are facing many difficulties in the process of rapid development, in terms of marketing are marketing lag, lack of innovation, talent shortage, serious lack of rational strategy and technical means backward, network marketing provides effective means to solve these problems. Based on the basic theory of network marketing, this paper constructs a network marketing relationship model, summarizes the main modes of network marketing, and puts forward some innovative countermeasures for marketing mode of small and medium-sized enterprises under the network environment. Specific measures include: from a strategic height to establish the network marketing concept and consciousness, strengthen macro-control, the development of network marketing of small and medium-sized enterprises to provide technical services, improve the network marketing network marketing sales and distribution cooperative network, to take the necessary measures to improve the quality of customer service.
\end{abstract}

\section{Introduction}

Marketing is an important link in the development process of an enterprise. It is a bridge and bridge between the production and social needs of a company. It can satisfy the needs of users by selling products, investigating the market, guiding production, creating demand and coordinating relations. Small and medium-sized enterprises (small and medium-sized enterprises), which are legally established in China, are conducive to meet the needs of the society, conform to the national industrial policies, and belong to small and medium-sized enterprises of all kinds of ownership and various forms of production and operation scale. Small and medium-sized enterprises play an important role in China's national economy, and have made great contributions to the promotion of economic development and the maintenance of social stability. For small and medium-sized enterprises that rely on "cost driving" and at the low end of the global industrial chain, facing the new trend of "re industrialization" in developed countries, competition is becoming more and more intense, and faces many difficulties and challenges in the process of rapid development. Especially in marketing, there are such problems as lagging marketing means, lack of innovation ability, shortage of talents, lack of rationality in strategy and great risk of technological innovation. These problems seriously hamper the development of small and medium-sized enterprises. In the increasingly fierce competition in the market environment, small and medium-sized enterprises want to seek survival and development space, to obtain a certain market share, we must fully realize the importance of marketing, take corresponding measures to the problems and shortcomings, give full play to the important role of marketing in enterprises development, improve marketing ability and market competitiveness.

The close combination of economy and network has promoted marketing into a new era of network marketing. Internet marketing is based on the Internet as the core platform, taking the network users as the center, taking market demand and cognition as the guidance, and using various network application means to achieve a series of behavior of marketing purpose ${ }^{[1]}$. Network marketing is a small and medium-sized enterprises in the transformation and combing the marketing mode of the mobile Internet era, which affects the internal marketing management of small and medium-sized enterprises, from structure design to update the marketing idea, to use marketing tools from the process, the marketing concept, marketing methods and marketing means to meet the 
needs of the market environment, to achieve harmony and unity the theory and method of marketing. Through scientifically and effectively optimizing the allocation of marketing resources, we use database analysis system to achieve real-time monitoring of marketing effectiveness, so that market management can make the right decisions and enhance the competitiveness of small and medium-sized enterprises. Aiming at the practical problems of SME marketing, this paper studies the marketing mode innovation of small and medium-sized enterprises under the network environment, serving the sustainable development of small and medium-sized enterprises in the Internet era.

\section{Network Marketing Relationship Model}

Online shopping is not only influenced by traditional shopping factors, but also influenced by network environment factors, and the network marketing process and network marketing strategy of Internet consumers are totally different from traditional marketing. Therefore, the network marketing model should not only be interactive, real-time and cross time and space, and the relationship between the basic network marketing transaction subject, but also to reflect the consumer purchase decision-making and marketing process, reveal the inherent link between consumer and enterprise network marketing fundamentally. According to this idea, we build a network marketing relationship model based on enterprise and consumer, which can fully reflect the characteristics of network marketing, as shown in Fig 1.

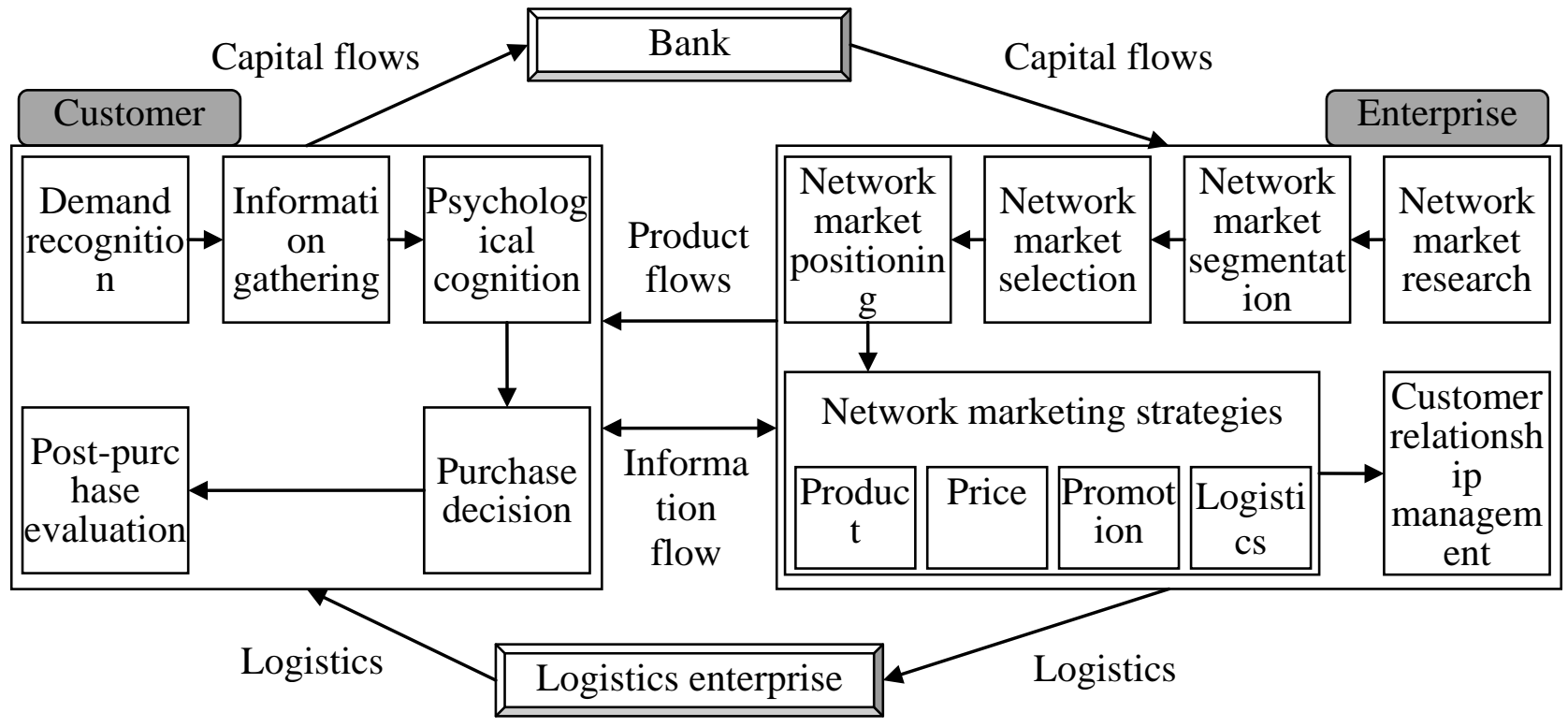

Fig 1 Network marketing relationship model

The network marketing model shown in Fig. 1 by consumers, marketers, banks and logistics enterprises is composed of four parts. Among them, the consumer purchase decision-making process is divided into "Demand recognition, Information gathering, Psychological cognition, Purchase decision and Post-purchase evaluation" five stages; the marketing process is divided into "Network market research, Network market segmentation, Network market selection, Network market positioning, Network marketing strategies and Customer relationship management" six stages. The different arrowhead lines in the graph represent the corresponding "Capital flows, Logistics, Information flow and Product flows".

\section{Basic Theory of Network Marketing}

The basic theories of network marketing include the following four:

(1) Direct response marketing theory ${ }^{[2]}$. Direct refers to the direct connection of enterprises and consumers through the media without the intermediate distribution channels. When selling products 
online, customers can directly place orders and payments to enterprises through the network. "Response" refers to the interaction between enterprises and customers. Customers have a clear response to this marketing, and enterprises can count the data clearly. The most important feature of network direct marketing is the interaction between enterprises and customers, which not only can get the interaction of orders, but also can get other data or even suggestions of customers, so as to achieve the satisfaction of both sides and continuous cooperation.

(2) Network soft marketing theory. Aiming at the new theory of "strong marketing" featuring large-scale production in the industrial economy era. Enterprises to convey information to customers and the use of promotional tools more rational, more easily accepted by customers, and then to achieve information sharing and marketing integration. Soft marketing theory emphasizes the customer's psychological experience, in sharp contrast with the strong marketing. In the current Internet era, strong marketing has been very rare, the concept of soft marketing infiltration in the daily marketing. Soft marketing emphasizes that marketing activities respect the feelings and experiences of consumers so that consumers can comfortably receive the marketing activities of enterprises.

(3) Relationship marketing theory ${ }^{[3]}$. Think of marketing activities as a process of interaction between enterprises and consumers, suppliers, distributors, competitors and government agencies, as well as other public interactions. The core is to establish and develop relationships with these public good relationship. The focus of relationship marketing is to sustain consumers and provide them with products and services that are highly satisfying. The realization of corporate marketing goals, often through the strengthening of contact with consumers and provide effective services, in order to maintain long-term relationship with consumers, and on the basis of marketing activities. To strengthen the contact with consumers and consciously cultivate customer loyalty can bring long-term benefits to the enterprise.

(4) Database marketing theory. The process of establishing, maintaining and utilizing customer data and other customer information in order to achieve the goals of engagement, trading and establishing customer relationships. Database marketing is not only a marketing method, tools, technology and platform, but also a business philosophy, changing the marketing and service model, but also changed the basic values of marketing. Collect and accumulate a large number of consumer information to predict the possibility of consumers to buy a product, the use of this information to the product to accurately locate, targeted marketing information, to convince consumers to buy the product.

\section{Main Mode of Network Marketing}

Marketing mode is very important for business operation. When conducting network marketing, enterprises need to choose a reasonable marketing mode based on their own characteristics, business nature and marketing objectives. Currently used in small and medium-sized network marketing model shown in Fig 2.

The network marketing model shown in Fig. 2 is briefly described as follows: (1) Search engine marketing, the most mainstream of a marketing tool, do not need too much cost, by small and medium-sized enterprises attention. (2) Instant messaging marketing, Internet marketing is the most common form of common tools, including QQ and WeChat. (3) Chat group marketing, is an extension of instant messaging tools, using a variety of instant messaging software in the group features marketing. (4) Viral online marketing, quickly spread the information within a short time, forming a powerful magnetic field, let the information boil, make the enterprise fame. (5) Network forum marketing, professional talent planning, promote corporate brand, products and services through creative text, pictures and video. (6) Network blog marketing, the use of personal knowledge of bloggers, interest and life experience and other products dissemination of information. (7) Network knowledge marketing, the use of information on the Internet site for corporate knowledge and product marketing. (8) Internet event marketing, carefully planned events for users to participate in, in the case of fun to help businesses expand the event. (9) Internet word-of-mouth marketing, marketing staff to communicate with target customers through word-of-mouth 
information, deepen the impact and impression of target customers. (10) Internet direct-response marketing, through the website directly to the end customer, the product marketing out. (11) Internet video marketing, a marketing tool that companies place various video clips on the Internet to promote corporate brand, product and service information. (12) Network picture marketing, will be creative pictures posted on the site, which was crawled by search engines, into the public field of vision. (13) Internet soft text marketing, very natural to show the propaganda of enterprises and products, but not public disgust marketing strategy. (14) Electronic subscription magazine marketing, subscribe to corporate magazines and log messages by e-mail, and get to know the needs of enterprise information.

\begin{tabular}{|c|c|}
\hline \multicolumn{2}{|c|}{ Network marketing mode } \\
\hline Search engine marketing & Internet event marketing \\
\hline Instant messaging marketing & Internet word-of-mouth marketing \\
\hline Chat group marketing & Internet direct response marketing \\
\hline Viral online marketing & Internet video marketing \\
\hline Network forum marketing & Network picture marketing \\
\hline Network blog marketing & Internet soft text marketing \\
\hline Network knowledge marketing & Electronic subscription magazine marketing \\
\hline
\end{tabular}

Fig 2 Main mode of network marketing

\section{Innovation Countermeasures on Marketing Mode for Small and Medium-sized Enterprises in Network Environment}

Internet marketing broke the traditional mode of operation of corporate marketing, from different angles and different levels of profound impact on the company's marketing management ideas and methods. Internet marketing is a complex system engineering, but also the only way of marketing in the new century, has brought historical opportunities to the vast number of enterprises, but also poses a serious challenge. In view of the many limitations of small and medium-sized enterprises in the network marketing, with reference to the relevant literature [4-7], small and medium-sized enterprises in this paper put forward the network marketing environment innovative countermeasures are as follows:

(1) Set up the concept and consciousness of network marketing from strategic height. Strengthen publicity on the network marketing publicity, improve public awareness of Internet marketing, eliminate strangeness and mystery, enhance the sense of trust. Guide the vast number of consumers to change their eyes on the truth of the traditional shopping methods and shopping habits, psychological acceptance of its network marketing. For consumers, to change their own consumption concepts and traditional ideas, with the economic and social development, Internet marketing more room for development, and even will become the mainstream of the future marketing model, consumers should also adapt to changes in the trend, to accept the new Concept.

(2) Strengthen the macro regulation and control over the development of small and medium-sized enterprise network marketing. At present, the level of in formationization of small and medium-sized enterprises is low, and there is a lack of enthusiasm for developing electronic commerce. The government should resolve the negative factors as a positive factor, seize the opportunity to promote information technology, learn from the mature experience of developed countries, and strengthen the macroscopic regulation and control of the enterprise's development of network marketing. The establishment of a special fund for the development of small and medium enterprises online marketing, SME Internet marketing project loans to give interest rates, the 
financial sector for the development of small and medium-sized enterprise network to provide low-interest loans, tax departments for small and medium-sized enterprises to carry out network marketing activities tax-free.

(3) To provide technical services for network marketing. The government should establish a small and medium-sized enterprise information network and information release channel that is open to the whole society, such as policy information, technical information and market information, and improve the capability of information acquisition and information development of small and medium-sized enterprises. Actively guide and make use of domestic and foreign resources and rely on the intellectual achievements of institutions of higher learning and research institutes to carry out such work as web hosting, leasing equipment, website construction and system management, and strengthen knowledge popularization and personnel training for SME Internet marketing. , For small and medium-sized enterprises to carry out network marketing activities to provide technical support.

(4) Improve network marketing sales distribution network. Small and medium-sized enterprises should make good use of the accurate marketing model that has been set up to accurately find the target consumers and establish a logistics system suitable for the development of the enterprise. Logistics in the Internet age is the key to providing quality services. When consumers shop on the corporate online platform, the speed of logistics determines consumer satisfaction and the products of the enterprise must be quickly delivered to consumers. Small and medium-sized enterprises should cooperate with efficient logistics companies to realize the quick ordering of consumers on the Internet and quick delivery of logistics.

(5) Take the necessary measures to improve customer service quality. Whether traditional marketing or online marketing, customer service is the key to determining the success or failure of the business. Although the network has been able to achieve customer centered, but consumers often face a huge flow of information at a loss. For consumers want to maximize their own psychological changes, should further strengthen the customer service network marketing, tools commonly used, including e-mail, e-forums and FAQs. Enterprises according to the actual situation, the application of a combination of several tools and innovative means of service and ways to continuously improve customer service quality and enhance customer communication.

\section{References}

[1] L. Dong, "Research on the network marketing strategy of small and medium enterprises," China Management Informationization, vol. 13, no. 7, pp. 71-73 2017.

[2] Minnie's bolg, "Basis theory of network marketing," http://blog.sina.com.cn /s/ blog_ 7ee9de690100vhgk. html, 2018-1-2.

[3] Z. Y. Zhang, "Study of marketing model with Internet thinking: take Xiaomi Company for example," Master's Dissertation of Guangdong University of Foreign Studies, 2014.

[4] S. J. Yang, "Analysis of marketing strategy of small and medium sized enterprises from the perspective of network marketing," Market modernization, vol. 46, no. 19, pp. 33-34 2015.

[5] First paper network, "Investigation and Research on marketing mode innovation of small and medium sized enterprises under the network environment," http://www. 001lunwen. com/ shichangyingxiao/ 178421.html, 2018-1-2.

[6] L. L. Yu, "Research on marketing strategy innovation of small and medium sized enterprises," http://www. gwyoo.com/lunwen/shichanglunwen/yxcllw/201604/625808.html, 2018-1-2.

[7] X. F. Kang, "Research on the innovation of marketing mode based on Internet plus," Marketing Management Review, vol. 13, no. 6, pp. 78-79 2017. 